\title{
Economics Forged by Mass Communication and Scarcities. New Theoretical Framework -New Policy Prescriptions-New Scientific Thinking
}

\author{
Joergen Oerstroem Moeller ${ }^{1,2,3^{*}}$ \\ ${ }^{1}$ Visiting Senior Fellow, ISEAS Yusof Ishak Institute, Singapore \\ ${ }^{2}$ Singapore Management University \& Copenhagen Business School, Singapore \\ ${ }^{3}$ Honorary Alumnus, University of Copenhagen, Copenhagen, Denmark \\ Email: joergen@oerstroemmoeller.com
}

Received 1 December 2015; accepted 21 December 2015; published 24 December 2015

Copyright (C) 2015 by author and Scientific Research Publishing Inc.

This work is licensed under the Creative Commons Attribution International License (CC BY). http://creativecommons.org/licenses/by/4.0/

(c) (i) Open Access

\begin{abstract}
Economics does no longer deliver analyses and solutions to problems confronting the global economy and contrary to expectation it does not move towards general equilibrium. Two big transformations take place: Mass consumption is replaced with mass communication-the era of plenty is replaced by scarcities. Economic models have so far proven inadequate to tackle the turnaround from growth \& distribution of benefits to burden sharing leaving policy makers without advice and guidelines. The idea of economic thinking (homo oeconomicus) introduced by Adam Smith does not reflect realities in the beginning of the $21^{\text {st }}$ century. Concentration of economic activities in the hands of relatively few operators rules out competition in the sense of a free market. Distribution of income and wealth is steered by a mismatch between supply and demand of skills rewarding those who by chance have the "right" skills. The concept of work is changing fast as is the notion of companies with jobs being performed outside companies eroding the well-established Theory of the Firm. Bringing in other social sciences it becomes clear that people are less motivated by economic incentives than presumed, which makes it necessary to broaden economic analyses and policy making. Interdisciplinary and intersectoral thinking incorporating human behavior crowds out pure economic reasoning. In a longer term perspective the way ahead may be to base economic thinking and models on big data analyzing how data are linked to each other without any prior assumption of theory. The future for economics may therefore be to go from deduction to induction.
\end{abstract}

\section{Keywords}

Transformation, Mass Communication, Scarcities, Market Concentration, Work,

\footnotetext{
*Author of HOW ASIA CAN SHAPE THE WORLD, Iseas, Singapore 2010.

THE GLOBAL ECONOMY IN TRANSITION, Wspc, Singapore 2013.
}

How to cite this paper: Moeller, J.O. (2015) Economics Forged by Mass Communication and Scarcities. New Theoretical Framework-New Policy Prescriptions-New Scientific Thinking. Modern Economy, 6, 1279-1284. 


\section{Interdisciplinary, Deduction, Induction}

\section{Introduction}

Adam Smith's “The Wealth of Nations", published in 1776, intercepted the impact on the human mind-set of the industrial revolution grasping the swing from feudal thinking - mainly societal status, honor and dignity-to money (homo oeconomicus). Since then economics has wrestled with the question about explaining what is happening (descriptive), telling how to do things better (instrumental) or weighing into politics (normative).

Economics and economists missed the Wall Street crash in 1929. Indeed one of the greatest economists of that time, Irving Fisher, published shortly before the crash a thesis saying "Stock prices have reached what looks like a permanently high plateau". The same happened to the great depression in the 1930s, the oil price crisis in the 1970s, the Asian financial crisis in 1997, the 2008 global financial crisis and the subsequent recession in 2008-2009.

Economists find it difficult to find out what the science is about. The classical school reigned until the 1930s. It focused exclusively on production capacity, capital goods, investment and interest rate theories. In economic terminology the supply side was the only thing that mattered. This edifice collapsed with the great depression in the 1930s. John Maynard Keynes stepped forward with his "General Theory of Employment, Interest and Money" saying that the demand side-in reality consumption — was the core of economics adding that the public should steer total demand by spending in recessions and saving in boom times. This worked well for some decades but growing inflation opened the door for Milton Friedman who in the early 1960s advocated control of the money supply combined with free markets, and rejected any role for the state.

Theory tells that the system moves towards general equilibrium. As anyone can observe this is wrong; the system is in perpetual disequilibrium. In the 1950s the global economy saw unemployment, growing demand pressure ruled the agenda in the 1960s, stagflation (stagnation and inflation at the same time despite economics swearing that this could not happen) paralyzed economic policies in the 1970s, and deregulation of markets was the magic words in the 1980s. After a brief interlude with stability in the 1990s two major financial crises struck in the first decade of this century.

The purpose of this paper is to analyze the state of economics as a science. Established theories do not corroborate what is happening and it would be a grave mistake to dig in and expect realities to adjust to theory. Instead a diagnosis of discrepancies should be applied as a start to redraw the theoretical framework. Failures and shortcomings of existing policy prescriptions (economic policy) explain why the global economy despite strenuous efforts is still wobbling. Maybe the time has come to move forward and acquiesce to a new kind of economics or even the era of non-economics emphasizing the importance of other social sciences and why big data may force deduction out and induction in.

\section{The Big Transformations}

The global economy transits a transformation not seen since the industrial revolution. Mass consumption is giving way to mass communication. Knowledge must be shared to enhance productivity; people are only willing to do so if replicated by fellow human beings. Abundance of resources is replaced by scarcities-in some cases physically and in other cases economically pushing prices up. Burden sharing takes over from distribution of benefits; people are only willing to enter this social game provided that fellow human beings do likewise. The common denominator for mass communication and scarcities is analogous values connoting mutual trust pushing people to co-operate in groups. Utility theory, economic incentives, and homo economicus do not deliver because it supposes rationality and logic while it becomes more and more clear that human behavior is irrational, emotional and intuitive.

Knowledge is produced in enormous quantities. The impact depends on how easily accessible it is and the skill of the persons using it. More open societies benefit while closed and introvert societies struggle. Not only mutual trust among individuals, but trust between authorities and the people determine how knowledge is integrated in economic transactions. People want to share knowledge, but do authorities want them to do so and are authorities ready to share with the people? 
No genuine theory exists explaining what it cost to produce knowledge. Normal concepts like marginal utility and marginal costs are non-applicable. Except for initial investment, which in most cases is small, it does not cost much to produce. People are willing yes eager to produce knowledge and place it at the disposal of others (Wikipedia!). Furthermore knowledge introduces a much higher propensity to rent instead of owing. People get access to user facilities via the net and pay for the time they use a product or a service. Examples are Uber, Airbnp and "unlimited streaming" paying for access to catalogues.

Business have managed to turn an otherwise free good into a commercial product—profit seeking mode—by an alliance with the public sector smelling potential tax revenues. As the many examples of imaginative citizens demonstrate they operate on borrowed times; compressing a free good or service into a business model straitjacket does not look viable.

Firms/Corporations are explained by lower transaction costs-it is cheaper to gather workers, machinery and resources in one place than having them dispersed. It does not work quite like that in the era of mass communication. The prime factor dominating competitive advantage is fast becoming skills and competences. Knowledge and mass communication offer access to skills/competences irrespective of geography mobilizing skilled people wherever they are. Precisely the same tendency is visible looking at innovation. Corporations are allocating research to companies or persons outside the firm and connect them to the activities of the firm via the net. The advantages reaped outshine what loss in transaction costs if any is encountered by not having people at the same geographical place. The result is breaking up of the firm. Corporations/firms embark on structuring activities around digital networks kept together visually and not physically. The repercussions for costs and management are seminal; in reality mass communication heralds a new business model.

Scarcities have been announced many times. In 1798 Thomas Malthus [1] predicted that population increase would outpace food production resulting in famine and the Club of Rome launched its study 'Limits to Growth' in 1972 [2]. The difference is that currently we actually have scarcities/shortages. The Food and Agricultural Organization of the United Nations (FAO) [3] point to food shortages in 40 countries. The commodity index is falling, but despite technology and lower global growth still 50 percent higher than ten years ago. Countries and regions face water stress and in some cases severe stress that does seem to get worse (e.g. Southern California and Sao Paulo).

For the production function durability, reuse, regenerate, remanufacturing and recycle must be taken more into account. Product cycle defined as the total use of resources for goods or services replace the narrow minded view of solely looking at energy use. Resources are used producing a new good and disposing of the obsolescent one. Total use of resources over the total life of a product (life cycle) will be included in profitability. There has been much talk of 3-D manufacturing as a revolution in manufacturing. The genuine revolution will be 3-D disaggregation allowing an obsolescent product to be disassembled for the components to be recycled. Garbage and waste becomes precious not only looking at disassembling, but finding landfills to recycle resources now their weight worth "in gold".

The consumption function undergoes similar transformations. Durability turns into a competitive parameter making it impossible for companies to produce and sell products with inbuilt obsolescence as is the case nowadays in certain sectors especially electronic products. Consumers will expect "hardware" capable of exchanging "software" prolonging the life of the product - cell phones, fridges, and computers. 3-D may play a role in this. The change in values and attitudes may have a spillover effect on consumption. If a consumer postpones buying a car there is no guarantee that the car can be used in the same way five or ten years later. Restrictions may have been introduced limited the opportunities to use the car. People will focus more on happiness and well-being achieved through communication, services, doing something with others and for others growing out of mutual trust rooted in common and shared values (non-materialistic consumption). In the US the young generation is far less attracted by car driving than their parents. Surveys show that people in Asia look at companies' policy to give something back to society as an important part in branding. Physical well-being, tangible goods, and worldly possessions (materialistic consumption) yields as the main factor defining 'happiness'.

\section{Implications for Economics}

Students of economics learn that prices are set by supply and demand in a market. That may have been correct in the early days of economics, but no longer. In reality prices are set by a limited number of large corporations in a market with few players and limited competition (oligopolistic market). 1318 corporations control 80 percent 
of global business transactions - 147 control 40 percent [4]. In 1995 the Big Six US banks-JPMorgan, Bank of America, Citigroup, Wells Fargo \& Co., Goldman Sachs Group, and Morgan Stanley_had assets worth 17 percent of US gross domestic product (GDP). In 2005 the share had grown to approx. 50 percent [5]. After the global financial crisis it jumped to 60 percent. The two largest carriers in U.S. wireless Verizon Communications Inc. and AT\&T together control around 70 percent of the nationwide market. Add Sprint Corp. and TMobile and the share goes up to 90 - 95 percent [6].

This concentration allows the companies to play their own game. In the financial sector sophisticated financial instruments benefitting banks solely instead of oiling the economy are issued. The U.S. financial sectors share of GDP has risen from two percent in 1950 to eight percent before the financial crisis. This means that it encroaches on production without contributing more to growth. In the telecommunications sector companies commercialize what would otherwise be a cheap or even free good - knowledge.

Distribution theories focus on labor versus capital. The latest in the line of hundreds of books looking into this is Thomas Piketty's “Capital in the $21^{\text {st }}$ Century” [7] who argues that over time the rate of return on capital tends to be higher than economic growth tilting income distribution to the advantage of owners of capital. This is a typical industrial age analysis neglecting the skill factor. Skills of those operating machinery perceived in a broad sense determine marginal product. A premium is paid to those with a higher performance than those not having the skills in demand and consequently a lower performance. If a mismatch exists between supply and demand of skills this premium can be very high as seen over the last two decades with introduction of Information and Communication Technology (ICT) resulting in an almost explosive growth in inequality. Those having skills not in demand are crowded out of the high end job market forced to compete with middle level skills workers depressing the wage rate for this segment of the economy. Over the last decade the share of long term unemployment has grown rapidly in most industrialized countries while at the same time around 1/3 of U.S. businesses cannot fill vacant positions.

Since industrialization relative factor prices - in this context wage rate versus commodity prices-has steadily favored the wage rate making it profitable to save labor and use resources without any cost inhibitions. In the future scarcities and higher resource prices change relative factor prices to favor resources and depress wages. The first consequence is that production will be more labor intensive and less resource intensive. The second one is a lower share of GDP going to labor. Statistics show that Labor's share has fallen in the U.S. from 59 percent in 1980 to 55 percent in 2012 [8].

Industrial society benefitted from a kind of symbiosis between owners and workers both depending on the enterprise for prosperity. Now obscure and nontransparent funds take over ownership pursuing short-term profit goals primarily of financial character with little or no interest in the long term future of the enterprise. They hike the share price to resell or split the enterprise in separate divisions. This break-up of age old owner-worker relationships is followed by a similar break-up in business-society ownership with business' transferring costs to society. The financial crisis disclosed that financial institutions having lent recklessly transferred much of bad debt to the public sector-in economic jargon deleveraged debt while public sector debt rose. Redundant workforce is retrenched shifting the burden of taking care to the public sector. Many public services have been privatized and in some cases that may be good, but there are too many stories of privatization used to take money out of such companies e.g. in telecommunication and transport to feel comfortable-is it good for society? The taxpayers?

From the point of workers the corporation is becoming distant. The web and the cloud make it possible for workers to offer what they produce instead of their working capacity. As they can and do shift from company to company they, like the owners, lose interest in the long term future for the company. Tomorrow they can sell their product to another company.

Out of this comes an anonymous ownership and impersonal relations to companies breaking up the firm as we know it and introducing a business model much more focused on short term profit seeking and less interested in contributing to society.

\section{What Do Other Social Sciences Say?}

Anthropologists say that behavior is learned by watching other human beings. What is learned is cumulative in a generational sense-one generation passes it on to the next generation. Social environment-groups-becomes important because individuals learn inside a cultural framework. The more people seek together in groups and 
the better they function the more individuals learn and the more they pass on to future generations.

Homo oeconomicus is synonymous with individuals behaving selfish and seeking profit, but this theory is not upheld by studies outside economics such as psychology. Economists have defended their stand by saying that people may be generous only if they expect to be rewarded at a later stage, but neither this second line of defense is confirmed by studies outside economics. On the contrary, people are generous even if there is no prospect of later reward. Apparently generosity is built into our genes making it natural to share and help fellow human beings. One study looked at babies and concluded that watching people they showed a preference for figures that helped others.

Sociology comes to similar conclusions. The survival of the individual depends on the group he/she belongs to. Inside the group individuals may behave selfishly, but there is a clear recognition that cooperating and supporting each other enhances the survival prospect of the group and each member compared to groups where such behavior is less dominant.

\section{Conclusions}

The combination of economics' current problems and findings in other social sciences undermining or outright contradicting economic theory leaves no other option than bringing in interdisciplinary and intersectoral analyses. This kind of thinking highlights ability to combine and mix, predict consequences of doing something in one sector on other societal sectors and multitasking. Social networking finds its place by offering technology to combine information and knowledge without a deeper analysis and understanding. In short: A move from specialization to multitasking and combinations. The loser in this game is basic research and objectivity. The winner is multitasking and subjectivity.

When things are "normal", future behavioral patterns can be deducted from past behavior. In the midst of transformation things are not "normal" so people change behavior, making past behavior inconsequential. What we learn by watching other people and recalling our own reaction lose accuracy because past behavior was guided by events and surroundings not existing anymore. In "normal" times belief and observations coincided, reinforcing each other stabilizing the behavior of the individual. In changing times the opposite happens; the individual cannot handle events contradicting belief-what is termed cognitive dissonance blurs the picture paralyzing individuals.

For economics this makes modelling - the plinth of modern economics-close to a useless instrument. Modelling presumes cause-effect relationships to be stable or predictable repeatable which is only the case if past behavior is repeated and in times of change that is not the case-hence wrong forecasts from economic models.

Big data may provide the bridge to a new way of thinking by obliterating shutters isolating each social science in its own ivory tower. Utilizing big data reveals interdependence among various factors without a prior theory. Currently deduction confines economists to form a theory to be tested through appropriate economic tools. From theory to test to realities. Big data reverses that order starting with realities to be tested by common sense is followed by a theory if the interrelationship holds and passes the test.

We move from deduction having ruled social sciences to induction. Deduction narrows possibilities or alternatives as they need to conform to theory while induction is not constrained by a theory.

The swing around from deduction to induction combined with interdisciplinary and intersectoral analyses would provide us with much better tools to predict and forecast for the very reason that they will be much better to read and interpret human behavior.

\section{References}

[1] (2008) An Essay on the Principle of Population (Oxford Classics). Oxford Paperbacks 2008, Oxford Paperbacks, Oxford (First published in 1798).

[2] Meadows, D.H. (2004) Limits to Growth: The 30-Year Update. 3rd Edition, Chelsea Green Publishing, London (First published in 1972).

[3] FAO (2006) 40 Countries Face Food Shortages Worldwide. 9 October 2006, Rome. http://www.fao.org/Newsroom/en/news/2006/1000416/index.html

[4] Welt (2011) Diese Firmen Bestimmen Schicksal der Weltwirtschaft. http://www.welt.de/wirtschaft/article13680359/Diese-Firmen-bestimmen-Schicksal-der-Weltwirtschaft.html

[5] Johnson, S. (2012) Big Banks Are Hazardous to U.S. Financial Health. Bloomberg, 2 September 2012. 
http://www.bloomberg.com/news/2012-09-02/big-banks-are-hazardous-to-u-s-financial-health.html

[6] Reuters (2014) Top Four U.S. Wireless Carriers Increase Control of Market, Review Finds. 18 December 2014. http://www.reuters.com/article/usa-wireless-fcc-idUSL1N0U22PR20141219

[7] Thomas Piketty (2014) Capital in the Twenty-First Century. Belknap Press, Harvard. http://dx.doi.org/10.4159/9780674369542

[8] Economist (2014) The Third Great Wave. 4 October 2014.

http://www.economist.com/news/special-report/21621156-first-two-industrial-revolutions-inflicted-plenty-pain-ultimat ely-benefited 